\title{
Patterns and Factors of Natural Hazard Induced Out-migration from Meghna Estuarine Islands of Bangladesh
}

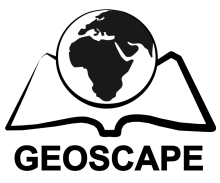

\author{
Rezwan Siddiqui* \\ Department of Geography and Environment \\ University of Dhaka, Dhaka, Bangladesh \\ *rezsid@gmail.com
}

\begin{abstract}
Migration behaviour of the Inhabitants of Meghna Estuarine region has been affected by several social, economic and natural causes. This migration has been thought as a part of social behaviour in this region. It has been predicted in several international researches that, human migration is going to be the worst possible effect triggered by the changing climatic scenario (IPCC, 2007). Natural hazards are also very much responsible for human migration. Purpose of this research is to find out the pattern and factors of natural hazards induced out-migration in Meghna Estuarine Islands of Bangladesh. In this empirical research, primary data has been collected through three-stage socio-economic survey. From this research it has been seen that, natural hazards like river bank erosion, saline tide, flood, cyclone, storms cause extreme havoc to the life and livelihood of the inhabitants of Meghna Estuary islands. Many of these situations force inhabitants to migrate temporarily or permanently. Indirectly these hazards also affects migration behaviours by affecting natural resources and income sources of inhabitants of this region. Natural hazards have two types of effect on migration behaviour; one is forcing rapid migration by riverbank erosion, cyclone etc. and the other is making situations for slow migration decision by disturbing the regular economic, social and environmental system. Two types of out-migrations are prominent in these islands; permanent household migration and partial migration - and these migration behaviours have been influenced by natural hazards of these study areas.
\end{abstract}

Key words: Bangladesh; Meghna Estuarine Islands; Natural Hazard; Out Migration

Received: 5 Jan 2014 - Revised form: 4 Jun 2014 - Accepted: 8 Jun 2014

\section{Introduction}

Migration on a temporary and permanent basis has always been one of the most important survival strategies adopted by people in the face of natural or man-made disasters (IOM, 2008). But with the intensification of natural hazards due to climate change factors, (NAPA 2005) the pattern of migration in Bangladesh especially in the off-shore islands of coastal areas might have been changed. This research aims to realize this issue of outmigration - forced or influenced by natural hazards in these highly vulnerable islands of Meghna Estuarine area of Bangladesh.

Before continuing into further discussion it is be better to give an idea about the administrative delineation system in Bangladesh. Bangladesh is divided into seven major administrative regions called divisions. These divisions are divided into sixty four districts and five hundred sub-districts or upazilas. Each Upazila (sub-district) there are unions which is the smallest administrative unit of local government- each consists of nine wards. Each ward consists of one or multiple mouzas or villages. Usually mouza and village boundary are same, but sometime they may differ. Village is more like a cultural entity that might change, but mouza is delineated by government authority. The word "Char" mean island in Bengali and in most cases island areas names are associated with the word "Char" (e.g. Char Nizam Kalkini, Char Montaz).

For this research three study areas have been selected for primary data collection from two major Meghna Estuarine islands: Manpura and 


\section{VERSIT $\Lambda$}

Hatiya. Sukh Char Union from Hatiya, Hajirhat and Uttar Sakuchia Union from Manpura were selected for the field research. For the convenience of primary data collection, Sukh Char mouza of Sukh Char Union, Char Geyan and Daser Hat mouzas from Hajirhat Union, and Char Nizam Kalkini (mouza) from Uttar Sakuchia Union were taken into consideration (Fig. 1).

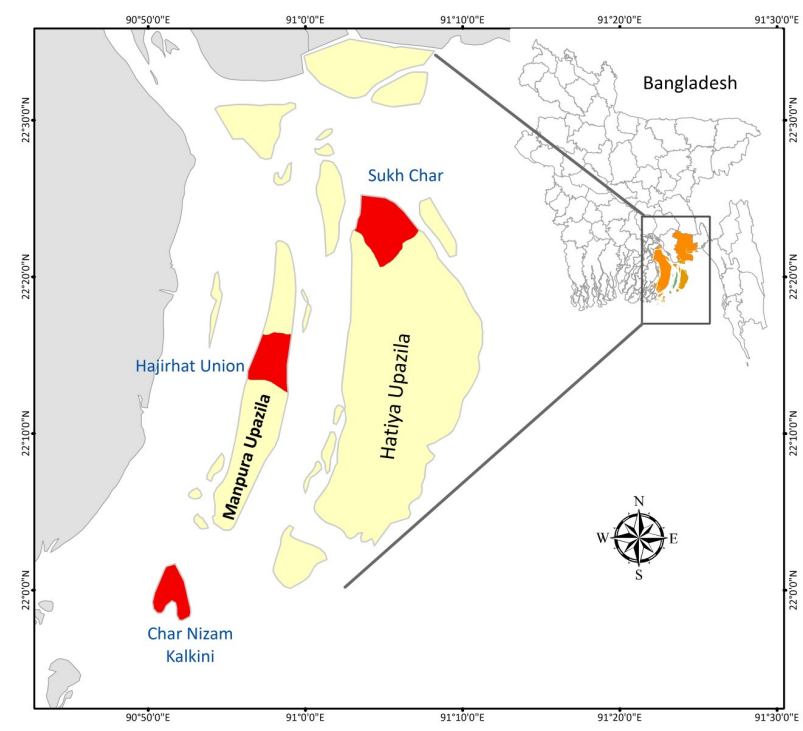

Fig. 1: Location of the study areas.
Sukh Char is one of the oldest habitats among Meghna Estuarine islands areas, once was highly populated, but now has rapid drop-off in population. Char Geyan and Daser Hat are situated within and surrounding Manpura Municipality, which gives them better social and economical facilities than any other area of these areas. Char Nizam Kalkini is a far remote island, with almost no social facilities for people living there. This char is habituated in very recent times comparing to the other two areas.

Manpura and Hatiya Upazila have very different growth rate of population comparing to the other estuarine islands. In 1981 and 1991, Manpura had a population growth rate (geometric) greater than country's rate $(2.354 \%)$ which is slightly lower than the country's population growth rate (1.39 \%) at present. On the other hand, Hatiya always have a steady rate of growth. But, different union of these two upazilas shows difference in their growth rate, somewhere low at an alarming rate (e.g. in Sukh Char Union $6.56 \%$ in 2011 and $-5.12 \%$ in 2001), whereas somewhere with steady higher rate (Hajirhat; $1.72 \%$ in 2011 and $2.83 \%$ in 2001) (see Tab. 1 for detail)

Tab. 1: Population, population growth rate of the study areas and their Upazilas for five census years Source: Bangladesh Bureau of Statistics

\begin{tabular}{|c|c|c|c|c|c|c|}
\hline \multicolumn{2}{|r|}{ Study Area \& upazilas } & 2011 & 2001 & 1991 & 1981 & 1974 \\
\hline \multirow{5}{*}{$\begin{array}{l}\frac{5}{\circ} \\
\frac{0}{0} \\
\frac{\pi}{3} \\
\frac{0}{0} \\
0\end{array}$} & Manpura Upazila & 76582 & 67,304 & 51,361 & 33687 & 17173 \\
\hline & Hajirhat Union & 25490 & 21,499 & 16,271 & 11974 & 4566 \\
\hline & Uttar Sakuchia Union & 32825 & 31,855 & 22,579 & 12924 & 5811 \\
\hline & Hatiya Upazila & 452463 & 341,176 & 295,501 & 234,869 & 208,616 \\
\hline & Sukh Char Union & 10569 & 20,841 & 35,266 & 26,417 & 23,920 \\
\hline \multirow{5}{*}{ 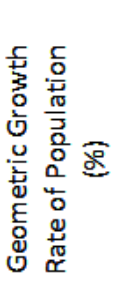 } & Manpura Upazila & 1.30 & 2.74 & 4.31 & 10.104 & \\
\hline & Hajirhat Union & 1.72 & 2.83 & 3.11 & 14.766 & \\
\hline & Uttar Sakuchia Union & 0.30 & 3.50 & 5.74 & 12.097 & \\
\hline & Hatiya Upazila & 2.86 & 1.45 & 2.32 & 1.708 & \\
\hline & Sukh Char Union & -6.56 & -5.12 & 2.93 & 1.429 & \\
\hline
\end{tabular}




\section{VERSITA}

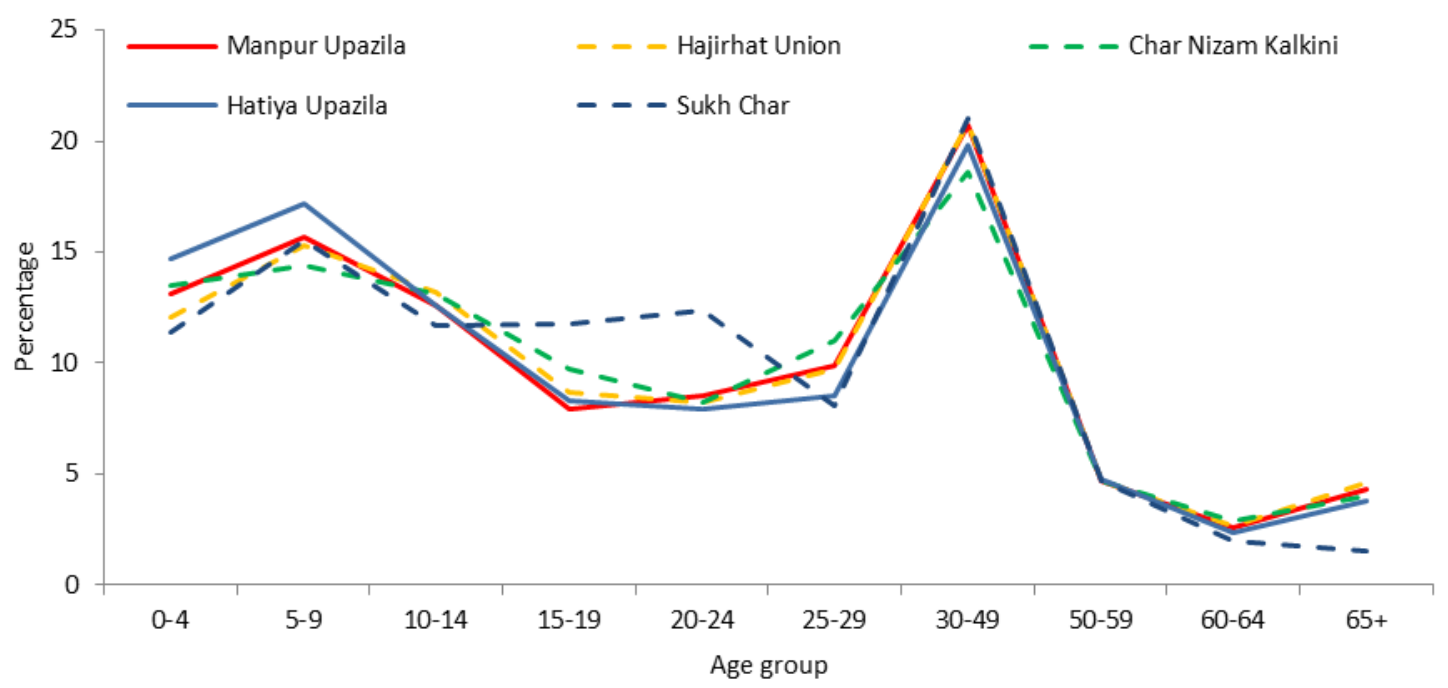

Fig. 2: Age group distribution of population in the study area and upazilas. Source: Bangladesh Bureau of Statistics

Tab. 2: Targeted households for field census survey and migrated/missing households.

\begin{tabular}{|c|c|c|c|c|c|c|c|}
\hline Study area & & & $\begin{array}{l}\text { Number of } \\
\text { households } \\
\text { (N) }\end{array}$ & $\begin{array}{l}\text { Targeted } \\
\text { households } \\
\text { (approx. } 10 \\
\text { percent }\end{array}$ & $\begin{array}{l}\text { Number of } \\
\text { households } \\
\text { missing }\end{array}$ & $\begin{array}{l}\text { Households } \\
\text { found in } \\
\text { field census } \\
\text { survey }\end{array}$ & $\begin{array}{l}\text { Percentage } \\
\text { of } \\
\text { households } \\
\text { missing/ } \\
\text { migrated }\end{array}$ \\
\hline Upazila & Union & Mouza & & & & & \\
\hline Hatiya & Sukh Char & & 2630 & 290 & 67 & 223 & 23.103 \\
\hline \multirow[t]{2}{*}{ Manpura } & Hajirhat & $\begin{array}{l}\text { Char } \\
\text { Geyan } \\
\text { Daser Hat }\end{array}$ & 677 & 85 & 15 & 94 & 15.310 \\
\hline & $\begin{array}{l}\text { Uttar } \\
\text { Sakuchia }\end{array}$ & $\begin{array}{l}\text { Char } \\
\text { Nizam } \\
\text { Kalkini }\end{array}$ & 296 & 26 & 2 & & \\
\hline Total & & & 3603 & 401 & 84 & 317 & \\
\hline
\end{tabular}

Hajirhat Union has the highest population density of 258/ kilometre2, and Uttar Sakuchia Union and Sukh Char Union have 220 and 103 per square kilometre respectively. Sex Ratio (male/ female) is also highest (105) Hajirhat Union and lowest in Sukh Char Union (98). From age group distribution scenario of population (Fig. 2), we can observe that Sukh Char has high ratio of population from 20 - 24 years and comparatively less in aged section (60 plus). Char Nizam Kalkini also has slight higher proportion of population of middle age.

Economy of the study areas are primarily agriculture and fishery based. $72.21 \%$ in Sukh
Char, $89.77 \%$ in Hajirhat Union, and $85.10 \%$ in Char Nizam Kalkini are involved in agro-based activities (BBS, 2012). Unemployment rate is far less in these study areas comparing to their respective districts. Industry based employment is only $2.72 \%, 1.91 \%$ and $4.10 \%$ in Sukh Char, Hajirhat Union, and Char Nizam Kalkini. According to the national survey literacy rate in these study areas are low in alarming rate: $30.4 \%$ in Sukh Char, $38.1 \%$ in Hajirhat Union, and $16.7 \%$ Char Nizam Kalkini. 


\section{Theoretical Background}

There are several estimations about the number of possible migration scenario for environment and climate change. The U.N. High Commissioner for Refugees (UNHCR) estimated that in 2006 there were 8.4 million registered refugees worldwide and 23.7 million internally displaced persons. According to Norman Myers (2002) by 2010, there were almost 40 million migrants, due to the environmental and climatic causes in the world and this umber will increase up to 200 million by the year 2050. He also pointed that in Bangladesh 26 million people are at risk of increasing global warming effects by 2050 . The 2006 Stern Review has used these numbers to measure the number of migrants in the context of climate change. Although these estimates are yet to be proved due to lack of strong empirical evidences, the number of environmental migrants is expected to rise in response to environmental degradation and weather extremes. (Scheffran, Battaglini, 2011). Coastal and riverine zones are among most vulnerable regions of climate change induced migration (Scheffran, Battaglini, 2011). Projected climate change is expected to severely affect people's livelihoods through intensification of natural disasters; increased warming and drought affecting agricultural production and access to clean water; rising sea levels making coastal areas uninhabitable and increasing the number of sinking island states (Martin 2009; Black et al. 2011).

In general, population mobility or movement includes all kind of spatial relocation from routine daily commuting to permanent migration that occur over various distances, and in which the duration of moves varies from a few hours to many years (UN 1970; Mahbub 1997). According to Zelinsky (1971), population mobility can be divided into migration and circulation. The distinction is on the basis of the degree permanent change of residence (Mahbub 1997). IOM (2004) defines migration as "A process of moving, either across an international border, or within a State. It is a population movement, encompassing any kind of movement of people, whatever its length, composition and causes; it includes migration of refugees, displaced persons, uprooted people, and economic migrants." Oliver and Smith (2010) considered migration as a failure to adapt in the context of climate change. This is encapsulated in the notion of "climate refugees" - an adaption of "environmental refugees" that refers to those who flee environmental crises in their homelands (Black 2001). These terms have been found both politically and analytically lacking as they do not offer protection under the Geneva Refugee Convention of 1951

For Bangladesh the most crucial impact of climate change will result in the migration of the people from coastal areas through the increases in the frequency and severity of chronic environmental hazards and sudden onset disasters (Barman et al. 2012). According to Black et al (2011) estimated numbers of environmental migrants in Bangladesh have been very high and are also project to increase in future. Black et al. (2011) have developed an integrated assessment approach to understand reseasons and patterns of changes in existing migration flows using examples from Bangladesh. Barman et al. (2012) did a questionnaire survey based research about migration patterns of disaster affected coastal areas of Bangladesh and found out that main reasons for migration are erosion and cyclone with flood, tornado and drought with a significant impact of climate change on the increase of the frequency and severity of certain hazards. Mayer (2011) and Black et al (2011) have identified and analysed permanent, temporary and circular migration as both adaptation and failures to adaptation to climate change - depending on status of communities and environment they are living in. Hussein and Nelson (1999) argue that migration forms a central component of risk mitigation strategies in the life of rural people. In the context of Bangladesh, natural disasters play a significant role in forcing people to migrate as a coping strategy (Rayhan, Grote 2007).

Two-thirds of the world's coastal disasters are associated with extreme weather events- which are likely to increase in intensity as a result of climate change (Adger et al. 2005; Morss et al. 2011). Dasgupta et al. estimated that in Bangladesh, 27 centimeter SLR (Sea Level Rise) and 10 percent intensification of wind speed 


\section{VERSIT $\Lambda$}

from global warming could increase the vulnerable zone in coastal Bangladesh by 69 percent. Given the present poverty related vulnerability and resilience, Bangladesh is in the first place of any climate change risk index (Newland 2011). In Bangladesh, most critical impact of climate change will result in the migration of the people from coastal areas to all over the country (Barman et al. 2012). A. K. M. Nurun Nabi (1992) suggests that high density of population works as a push factor and better opportunity for income works as pull factor. He has also opined the general trend of migration is from village to town areas in Bangladesh. In 2008, in EACH-FOR project report - they have identified several inconnected factors of migration in case of Bangladesh; emphasizing on economic condition as the major factor of migration. Environmental and climate change factors are complicatedly linked with economic factors and also between them. In this preject a country wide sampling method was used with two different types of questionnaires for migrant and nonmigrants. In 2012, Barmen et at. (2012) undertook a research to understand the migration patterns of disaster affected Subaarna char Upazilla, which is a charland in northern Bay of Bengal. They followed a single questionnaire method within a sample size of 49 . They found that erosion and cyclone strongly influencial upon migration behaviour of this region.

\section{Objective and Methodology}

Objective of this research is to find out the types, characteristics and factors of migration induced by natural hazard induced from the Meghna Estuarine islands of Bangladesh. An understanding of this migration scenarios and factors will help the policy makers to develop policy to tackle this migration issue properly in future. This paper aims to address following issues:

- Extent of natural hazards in Meghna Estuarine Islands

- Effect of these natural Hazards on outmigration directly or indirectly

- Routes and types and of migration originated from the study areas
This research follows inductive approach of geographical research. This is a descriptive type of research, analysing all the causal relationship of the observed population with the research problem. Both qualitative and quantitative approaches have been used in the study as a source of data.

In designing field survey, this research follows the methodology implemented by Mahbub (1997) in case of identifying mobility behaviour of working people in rural Bangladesh. A ten stage field survey was done in that research - which has been modified to fit into current research.

\subsection{Sample and Sampling Design}

In this research, three different methods of data collection of field survey have been carried out. So, three different types of sample system and sampling design have been implemented.

\subsubsection{Field Census Survey}

In Bangladesh, there is a "household list" that belongs to local government. This list consists of the name of the household heads by whom the households are recognized and also the number of family members. The targeted sample size was 10 percent of the population of the study area. For the convenience of survey, more than 10 percent of household were selected from the household list of Union parishad, using random number table. On an average 10 percent of the targeted population was surveyed in this field census survey (Tab. 2). Advantage of this method is the researcher doesn't have any control over the respondent selection process, so this method easily avoids biasness. Respondents from all economic and social status are randomly selected and respondents are also spatially well distributed all over the study area. Thus, the survey opinion reflects the actual facts and opinion more wisely. In this survey, information were mostly gathered from the household head, in absence of him/ her from the second adult person in charge of the family. In this method randomly selected households are unevenly distributed over the targeted study area, and so it takes much more time and labour to collect data in this method. Purpose of this primary survey is 
to find out the amount of migrants and migrated families. These informations were later used in the following two surveys.

\subsubsection{In-depth Sample Survey}

The defined size of the sample for this survey was approximately 50 . This has been done using two different criteria. First of all, all the families with migrant any family members were included in this survey and the rest of survey was done using the 'Area Sampling' method. In this survey an in depth and detail questionnaire was used to identify the cause of migration and impact of natural hazards upon this migration.

\subsubsection{Focus Group Discussion (FGD)}

FGDs have been conducted using the "Convenience and Purposive Method of Sampling". The predetermined size of this sample was 20 and the methodology was nonprobabilistic. There was a prepared questionnaire for this FGD, which was flexible depending on the situation. Discussion about and around the topic was encouraged to gather actual information as much possible. Major goal of this FGD is to collect community opinion about the migration status and factors. Information collected from the indepth survey were rechecked here with the participants, thus this help us to validate the information.

Landsat images of 30 meter resolution were extracted from 1977 to 2009 to identify erosion scenario of these areas. SRTM DEM have been analysed for flood depth and flood level analysis. Data from BCA (2004) has been used to show salinity level of the area.

\section{Result and Discussions}

\subsection{Natural Hazards in Meghna Estuary Islands}

\subsubsection{Riverbank Erosion}

Major physical processes in the Meghna Estuary region are related to the dynamics of water and sediment. Strong water flow cause erosion of riverbanks and contributes to the flooding of unpoldered lands. During dry season, sediments are re-arranged and mainly deposited near the coast and thus new land is formed. A net accretion rate of about $19 \mathrm{~km} 2 /$ year has been observed for the last 50 years, which is nearly 2.5 times higher than the long-term (150-200 years) accretion rate. This land, however, is not a replacement of the fertile land lost to erosion. They are muddy, salty, and lack nutrients. It takes many years before they can be used for the cultivation of crops (Sarker et al. 2003). Soils of the study islands are predominantly clay loam with some loam texture and these characteristics of the soil of this study area, makes them vulnerable to erosion more. In order to identify the riverbank erosion and its extent and measurement, remote sensing tool and GIS technique are used. Satellite images from 1977 to 2009 have collected, processed and analysed to identify the changes in landforms of the studied areas due to riverbank erosion. From the analysis of LANDSAT images it has seen that in last 40 years around 170 square kilometres of and has been eroded. Massive erosion has taken place in Northern and Northwestern part of the Hatiya and Manpura (Fig. 3). These places are far more populated than any other part of this Upazila; as a consequence, this riverbank erosion affects greater number of people. In the study areas, every family has a record of some kind of migration or relocation of their household(s) in last two generations. Some families have moved six to seven times due to this erosion. On an average every family have moved on 5.3 times in their lifespan.

\subsubsection{Tropical Cyclones}

In recent years more cyclones with higher wind speed and associate water surge have visited the coast of Bangladesh (NAPA 2005), and these remote islands of Meghna Estuary are vulnerable to each and every one of those cyclones. Fall of cyclones with greater intensity has been increasing (Fig. 4). Most adverse impacts of any cyclone in Bangladesh are resulted from the inundation due to cyclone surge and Meghna Estuary is the area of the surge amplifications mostly (WB 2010). People of Meghna Estuary islands, like Char Nizam, Hatiya and Manpura is now more vulnerable for cyclone and associated hazards than any time before. 


\section{VERSIT $\Lambda$}

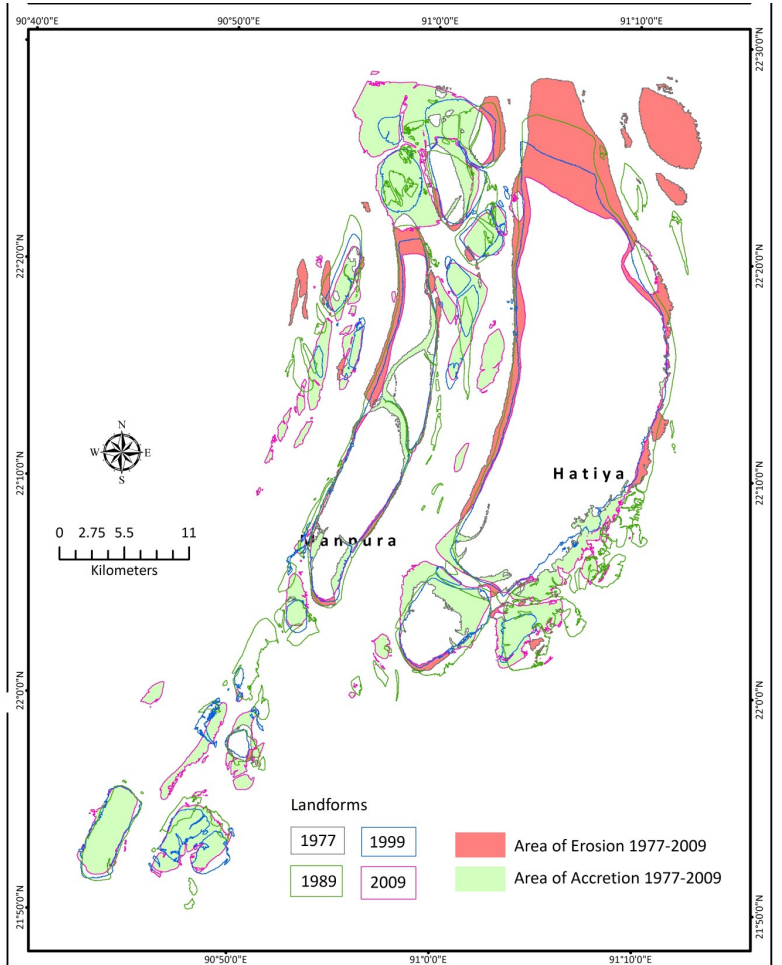

Fig. 3: Erosion and accretion of the study areas (19772009)

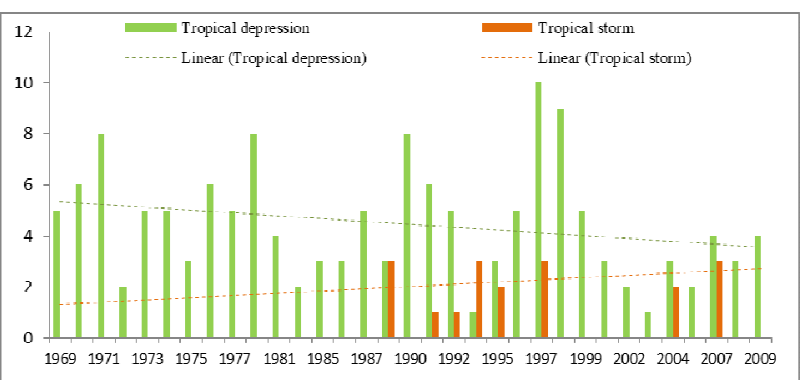

Fig. 4: Tropical Cyclones of Bangladesh. Source: UNEP/ UNISDR, 2011

\subsubsection{Saline Tide or Salinity Intrusion}

Both human interventions and climate changes are likely to change the prevailing processes of fresh water flow in the Meghna estuary especially during the dry season. Upstream water withdrawal may contribute to further landward salinity intrusion Higher sea levels will change the tidal motion in the estuary, especially during the dry season. This will have an impact on the sedimentation and erosion processes. Landward salinity intrusion during dry periods may increase (Sarker, Choudhury 2003).

(C) Jan Evangelista Purkyně University in Ústí nad Labem

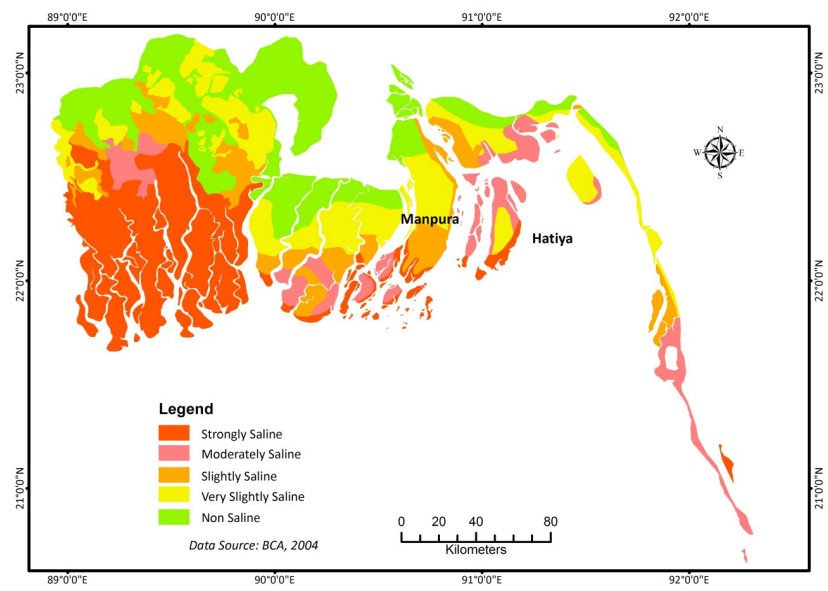

Fig. 5: Soil salinity level of the Meghna Estuarine Area. Source: BcA 2004

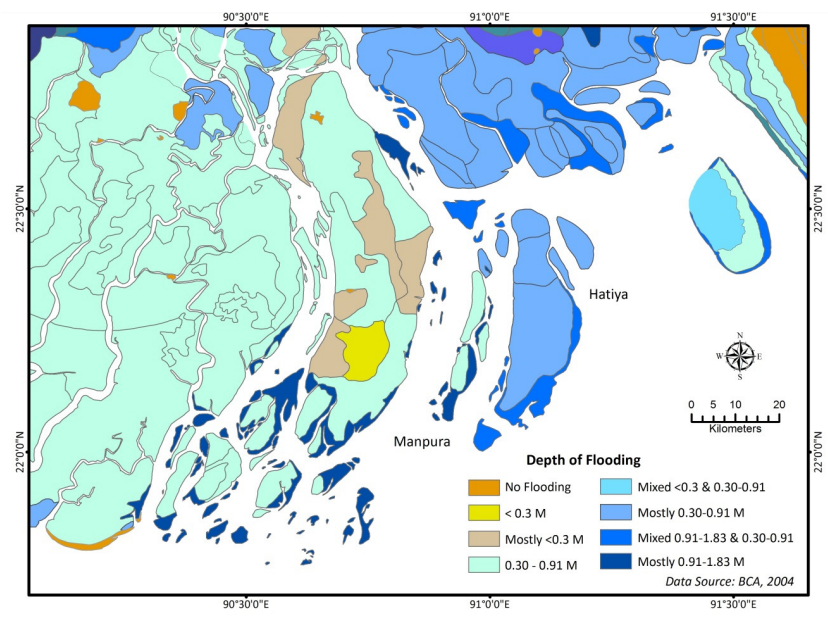

Fig. 6: Flood zones in Meghna Estuarine Area. Source: BCA 2004

In four different tidal stations of Bangladesh Water Development Board (BWDB) around Meghna Estuary, salinity level has been increasing from the year 2004. In Fig. 5, different soil salinity level of Meghna Estuary areas have been delineated. It has shown that the Southern parts of study islands are more saline in nature. From the field survey, it was evidently understood that areas with low elevation and prone to seasonal tidal flood are much prone to salinity. Moreover, thin layer salt crusts over agricultural land have made them unusable for traditional agricultural purposes.

\subsubsection{Flood and Water Logging}

Twenty five percent of area lies below three meter height from sea level, as a result these vast 


\section{VERSIT $\Lambda$}

areas are in threat of daily tidal flooding, as the average height of high tide in the study area is around three meter. Because of the very low elevation, these islands are subjected to severe water logging - water drains in during storm surge or tidal flood, but cannot drain out spontaneously. During field survey it has been observed that, many inland parts were flooded during tidal flood and became unusable for agricultural practices. Majority percentage of the study areas are prone to 0.3 to 0.9 meter flooding with some areas prone to up to 1.83 meter of flooded depth (Fig. 6).

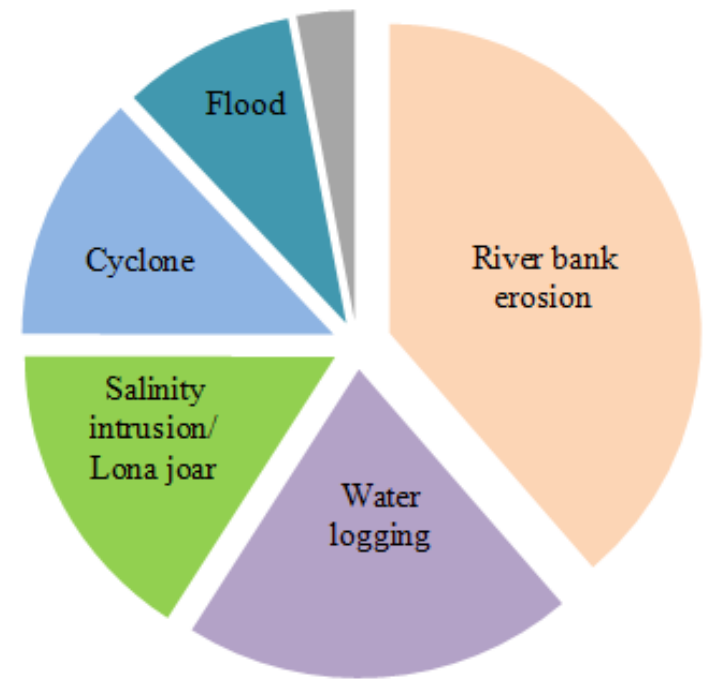

Fig. 7: Natural Hazards influencing people's decision of out-migration. Source: FGD 2012.

5.2 Natural Hazards as Push Factors of Outmigration

In Meghna Estuarine Islands, people are living as a part of nature, extracting enormous amount of resources from it. On the contrary, their life is extremely affected by the destructive behaviours of nature every year. Severe riverbank erosion and frequent floods and cyclones led to the permanent destruction of households and agricultural land in this area. In recent years, water logging and increase in salinity has added a new dimension of problems - destructing cultivable land and led to food shortage and migration. It has been seen that, river bank erosion is most prominent of all along with increasing salinity intrusion and more frequent saline tide affecting normal way of life of inhabitants of this area. Water logging, is another problem caused severe damage to the life of the island's people. Natural hazard of cyclone and flood is still prevailing but according to the respondent those are far less significant as factor of migration than the other natural phenomena mentioned. Fig. 7 shows the comparative effect of different natural hazards on migration decision.

\subsubsection{Increasing Intensity of Natural Hazards and} Disaster Damages

Ninety two (92) percent of the respondents have opined that the intensity and frequency of natural hazards have increased. Around eighty (80) percent have stated that the destructions created by these natural hazards are far more devastating than past .Again in the focus group discussions, more than eighty five (85) percent of the respondents indicated that effects of natural calamities are far more aggravated at present, than any time before. And all these effects are working as a pushing factor for migration of people and families from the study areas. Ninety five (95) percent of respondents in FGD mentioned the name of any natural disasters as a cause for migration. Most of them mentioned riverbank erosion, water logging, salinity and saline water tide as a push factor for migration.

According to Nironjon Kumar Das, headmaster of Maksudia Govt. Primary School of Sukh Char;

"Inhabitants of these regions are very much adaptive with the cyclones and storm surge. They had learnt to cope up with this natural hazards from generation to generation. But, they can't fight with riverbank erosion, salinity intrusion or saline water tide and the water logging - these are creating more problems than past and destroys the crops, habitat, lands and pushes to people migrate to somewhere else."

Another respondent of focus group discussion Ashraf Majhi said;

"Water of Meghna River is more saline now. When this water moves into inland, it destroys the productivity of agricultural land and fresh 


\section{VERSIT $\Lambda$}

water ponds for a long time. In past there were many fresh water ponds in Sukh char, but saline water have made them unusable. So, agricultural productivity is declining and people are now pushed to flee away"

Riverbank erosion is identified as the major cause for influencing out-migration. People lost their valuable houses and agricultural land by erosion, and as most of these people do not have economic comfort or any insurance to support them, they have no other way without migration. There are some indirect consequences of riverbank erosion also; like many important economic organization (e.g. markets, schools, industry) have demolished and this weakens the economy of this area. Riverbank erosion has often cause damages or complete demolition of the embankments that protects this islands from high tide and saline water intrusion.

Tab. 4: Status of income and income sources in last 10 years. Source: In-depth Sample Survey, 2012

\begin{tabular}{|c|c|c|}
\hline \multicolumn{2}{|r|}{ Percentage } & Reasons \\
\hline \multicolumn{3}{|c|}{ Changes in Income in last 10 Years } \\
\hline Decreased & $73 \%$ & $\begin{array}{l}\text { - } \quad \text { Loss of land due to riverbank erosion } \\
\text { - Decrease in fertility of land due to salinity } \\
\text { - } \\
\text { - } \quad \text { Dopulation increased but not the opportunity for work } \\
\text { educational institutions etc. }\end{array}$ \\
\hline Increased & $06 \%$ & \\
\hline Remain same & $21 \%$ & \\
\hline \multicolumn{3}{|c|}{ Changes in Agricultural Production in Last 10 Years } \\
\hline Decreased & $87 \%$ & $\begin{array}{l}\text { - Loss of agricultural land } \\
\text { - Decrease in fertility of land due to salinity or saline } \\
\text { tide } \\
\text { - Damage of crops from surge, cyclone, flood }\end{array}$ \\
\hline Increased & $13 \%$ & \\
\hline Remain same & $0 \%$ & \\
\hline \multicolumn{3}{|c|}{ Changes in Animal Husbandry Production in Last 10 Years } \\
\hline Decreased & $20 \%$ & $\begin{array}{l}\text { - Cattles washed away in surge, flood or storm } \\
\text { - Decline of grassland due to salinity }\end{array}$ \\
\hline Increased & $64 \%$ & \\
\hline Remain same & $16 \%$ & \\
\hline \multicolumn{3}{|c|}{ Changes in Fisheries Production in Last 10 Years } \\
\hline Decreased & $96 \%$ & $\begin{array}{ll}\text { - } & \text { Don't know } \\
\text { - } & \text { Overexploitation } \\
\text { - } & \text { Destruction of the breeding ground of fish } \\
\text { - } & \text { Unauthorized catching of fry fish }\end{array}$ \\
\hline Remain same & $04 \%$ & \\
\hline
\end{tabular}




\section{VERSITA}

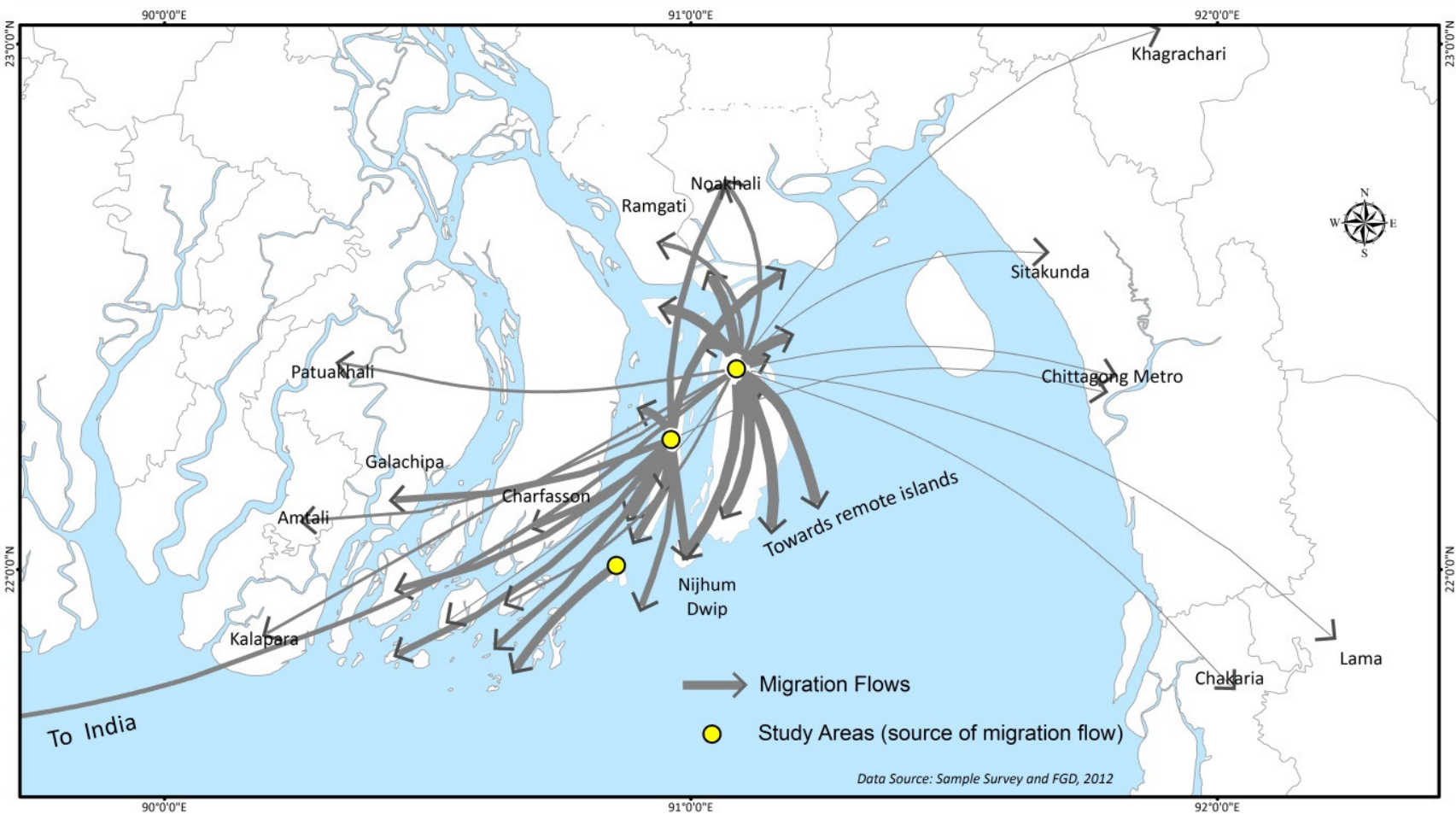

Fig. 8: Routes of Out-migration from Study areas.

Tab. 5: Pattern of seasonal circular migration in Meghna Estuarine Region. Source: FGD 2012

Mid April-Mid June

\begin{tabular}{|c|c|}
\hline & Mid April-Mid June \\
\hline \multirow{5}{*}{ Live in } & Outside the village \\
\hline & for work, mostly in \\
\hline & other villages of \\
\hline & mainland \\
\hline & Rickshaw puller, brick \\
\hline \multirow{3}{*}{ Work as } & field worker, farm \\
\hline & labor, and any sorts \\
\hline & of day labor \\
\hline
\end{tabular}

Mid June- October

Fishing and Cultivation Season

\section{October - Mid \\ December}

Mid December- Mid

April

$\begin{array}{lll}\text { Within their } & \text { Mostly in their } & \text { Outside the village for } \\ \text { village } & \text { village, some starts } & \text { work, mostly in other } \\ & \text { to move outside. } & \text { villages of mainland }\end{array}$

Fishing, Fishing, Agriculture,

Rickshaw puller, brick Agriculture, daylabor in fishing field worker, farm day labor in industry. labor, and any sorts of fishing day labor 


\section{VERSITA}

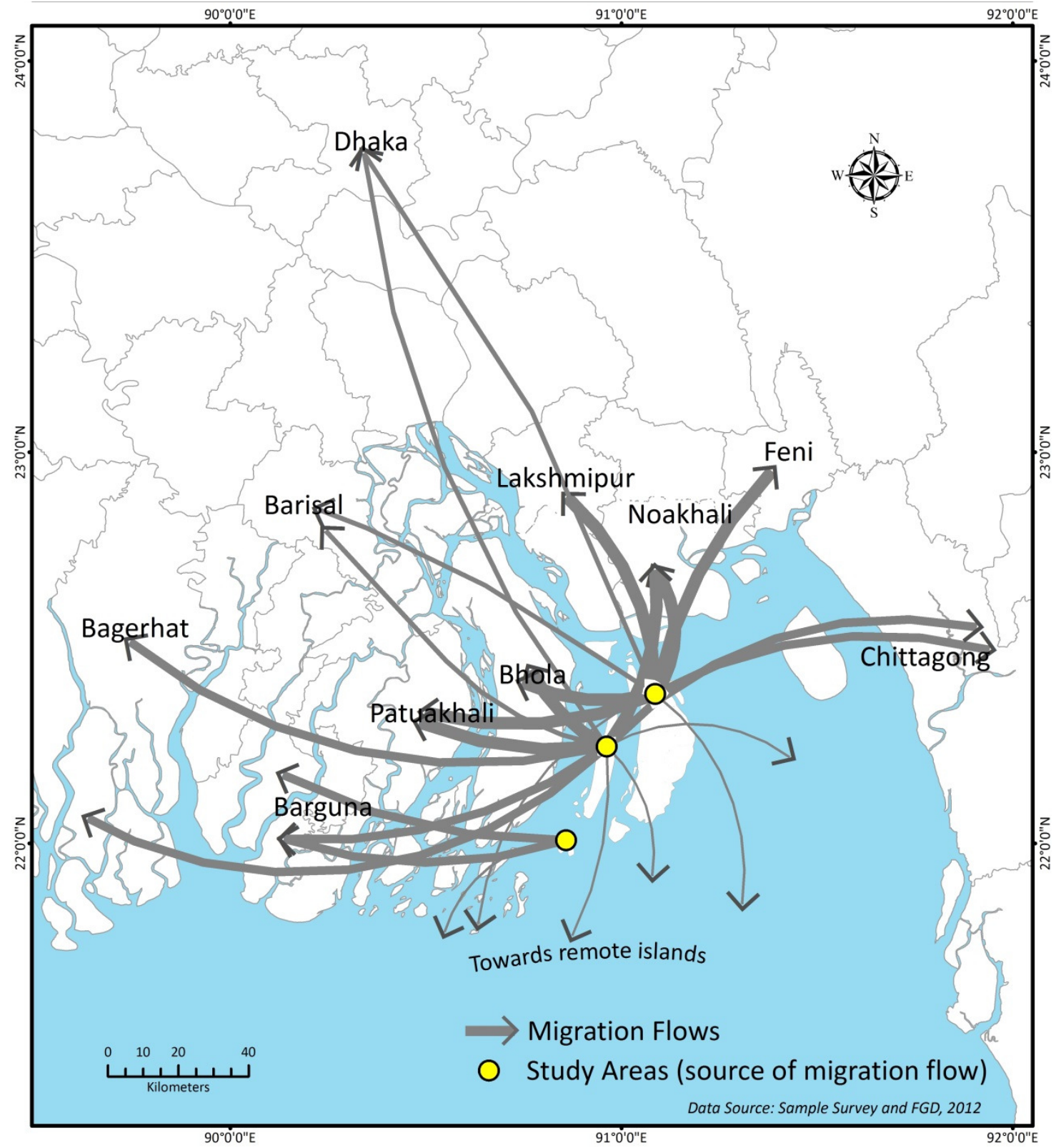

Fig. 9: Route of seasonal circular migrants of the study areas.

For the massive fresh water flow of Meghna River and associated estuary, salinity was never treated as a problem here. But now, majority of the respondent have mentioned "Iona joar" (local name for saline tide or salinity intrusion) as a major problem to their livelihood. They have also opined that the salinity of the water have increased compared to past. This saline water when flooded the area, cause long term damage to the productivity of agricultural land and fresh water reservoirs. Many fresh water reservoirs have become unusable due to this salinity intrusion. Fertility and productivity of agricultural land have been decreased in an alarming rate for the last few years - traditional cropping systems have been disturbed. Water logging is another new dimension of natural problem in the islands creating havoc to agriculture, communication and people's living. All these issues related to natural hazards, intensified the poor condition of living the inhabitants living in this area, an influence them to take decision to migrate.

At present these islands are more frequently affected by the flood, water logging and saline tide because of damage to the embankments and levees by the massive erosion. Cyclones and 


\section{VERSIT $\Lambda$}

associated storm surges are always a great threat to the life and property of the people of these island areas. The last great cyclone SIDR caused a huge loss in economy, life and property.

\subsubsection{Affects of Natural Hazards on Human Inhabitation and Livelihood}

Men have two priority sector of his/ her social life, one is his inhabitation and the other is his occupation. In Meghna Estuary region, both of these primary elements of men's social life are disturbed by natural hazards. Fishermen and peoples dependent on fishing are facing most problems by natural hazards, followed by the day labourers. And farmers and people related with farming facing problems in their dwelling and living. From the survey, it has also been seen that the businessmen and service holders are much free from these problems of effect of natural hazards on their livelihood or inhabitation because of their better economic condition and less dependency on nature. Extreme effects of natural hazards are more prominent on human inhabitation and dwelling, comparing to the sectors of livelihood. In this research more people have reported extreme level of environmental problems at their present home environment. This will help us to understand the answer of the question, "why people migrate?" The answer is may be "as they face problems in their living". It is obvious that, when people or community faces any problem in their life, they want to mitigate it or get rid of it - and migration, chiefly the out-migration works as a favourite option for them.

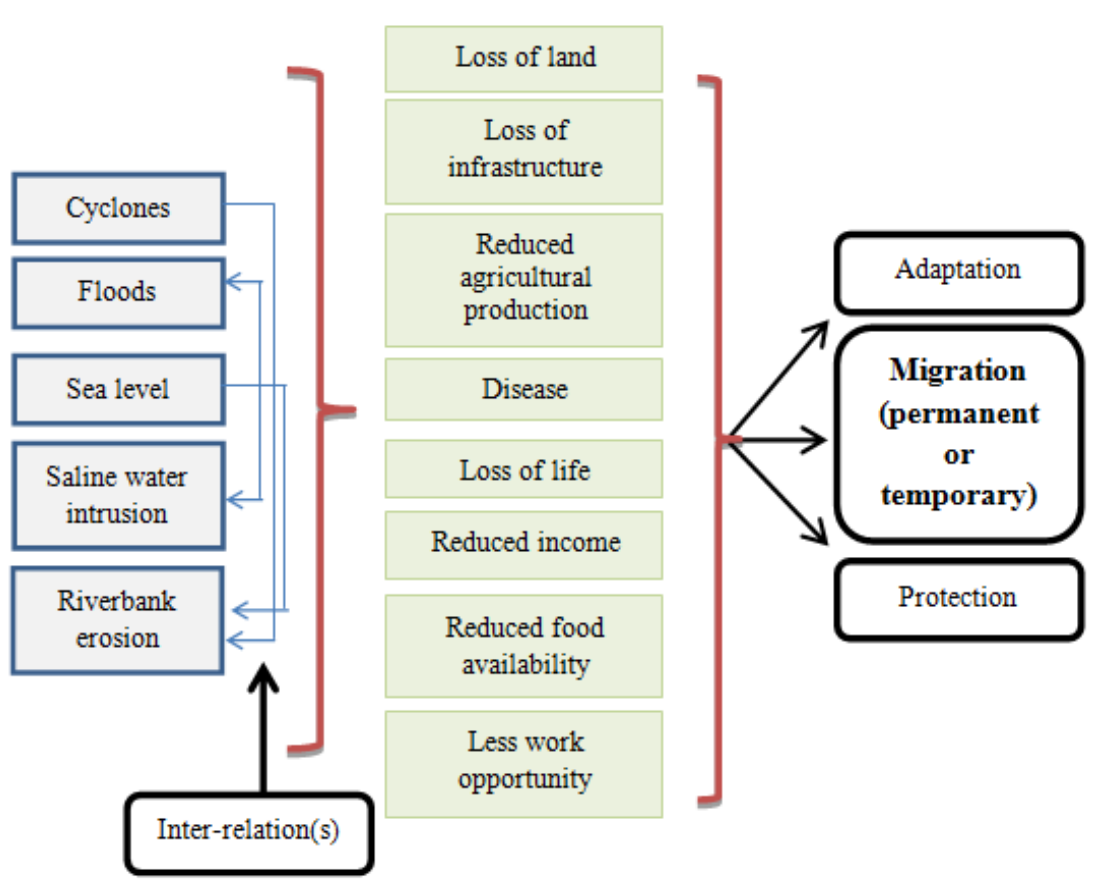

Fig. 10: Simplistic model of relationships between natural hazards with human migration.

\subsubsection{Impacts of Natural Hazards on Income and} Income Sources

Natural hazards in many cases are responsible for reducing income of the affected people. Respondents of sample surveys were asked about their present status of income and trend of income growth. The information is summarized Tab. 4. Excluding animal husbandry, production rate has been declined in all other sectors in last 10 years. Respondents also mentioned the reasons behind these decrease of production rate and income, and all these reasons are very closely related to the natural hazards (flood, water logging, cyclone, riverbank erosion salinity intrusion etc.). This situation often led to take 
out- migration decision in search of better livelihood.

\subsection{Types and Routes of Out-migration}

Two major types of mobility behaviours have been found in this Meghna Estuarine islands.

(a) Permanent household out-migration

(b) Partial migration

\subsubsection{Permanent Household Out-migration}

For the field census survey of this research, households were targeted using household list of respective union parishad. A lot of households were found missing, most of them have reported to left the village recently. Among all the households chosen by the random number tables from the household list, around eighty two (82) families were found permanently migrated from selected study areas. These families are enlisted in the household lists, but were not present there. $25 \%$ percent families in Sukh Char of Hatiya and $15 \%$ from Hajirhat of Manpura have found to be migrated permanently, mostly within last 2-4 years, so that they are still in the household list of the respective unions (Tab. 2).

It is hard to determine absolute number of migrants from any area in Bangladesh, as there are no records for this variable kept in any national record. More than 96 percent of respondents have reported that in last 10-15 years, on an average eight families of their close relatives and neighbours have been migrated from villages. Majority ( $82 \%$ ) of the individuals expressed their opinion that peoples and families are migrating from their villages and also from surrounding areas. It has also been found out that in last 20 years more than 500 families have migrated from Sukh Char Union and around 200 families from Hajirhat Union. Finding out destinations of the permanent migrants of these study areas is a part of the objectives of this research. This information was collected through field census survey and was cross checked with sampling survey. Most of the participants have strongly expressed their opinion to the fact that peoples and families migrated from this areas are never willing to go to city areas, rather they like village areas as their destination for migration.
This reason behind are cheap lands, well-known environment and social settings. New born nearby islands of Meghna Estuarine are the majorities' choice as a destination of migration. Newly accreted lands of present islands are the second best choice of the migrants. These intraisland migrations are very much prominent in this region. Migrations towards nearby mainland, mainly small towns and cities have also been noticed but are less prominent than intra-island types. People with economic solvency mainly do this kind of migration (Fig. 8).

\subsubsection{Partial Migration}

There are two types:

\section{(a) Seasonal Circular Migration}

People from Meghan Estuarine Islands have found to move outside of their villages to earn money. Usually the duration of this kind of migration is one month for women and three months for men (Ahmad 2003). This type of mobility behaviour is very common within the landless poor community of this area. Most of these people are day labourer, small farmers and fishermen, who can't make enough money in their native villages during off season. Tab. 3 gives us an idea about the seasonal migrants and their movement characteristics. These people don't have any occupational training or expertise to work in any specialized industry. As a result, most of them move on to other villages or small towns and cities of mainland and work mainly as a day labourer. Route for seasonal circular migration have been shown in Fig. 9.

Fishermen from these areas sometimes temporarily moved to further remote islands inside sea, to catch fish for duration of 7-30 days. When they live there, sometimes they make temporary shelter on those remote islands. Most of the time, they used this temporary shelter for several times in a fishing season. During fishing season, fishermen, boatmen, and day labourers from nearby villages and islands, temporarily settle in Sukh Char. They stay as long as the fishing season continues. In Sukh Char, every year around more than 2000 people come and stay from outside. These people, don't live on the land, or rented house. They stay on their fishing boat and fish around Sukh Char. Most of the 
people involved in agriculture have lost most of their lands in riverbank erosion and the remaining lands are sometimes not cultivable for water logging. As they can't make enough to earn their bread, they also seem to move outside of their villages in search of work.

\section{(b) Permanent Migration of Family Members}

This type of migration behaviour is very few in the study areas. Only six percent of the families have any members migrated outside permanently, and all of these six percent families are economically well off. Rich families usually sent their family members in search of better livelihood, education etc. This migrant family member(s) has occasional visit to their home to meet their relative and for family matters.

\section{Conclusion}

A simplistic model for factor of migration has been generated from this research (Fig. 10). Natural hazards have been found as both active and passive factor for out-migration from Meghna Estuarine Islands. Riverbank erosion, water logging or flood and saline tide were mostly prioritized by the respondents. Natural hazards have been acting as direct push factor for migration through destruction of and resource, and as indirect factors through its effect upon human livelihood and income. Continuous natural hazards are responsible for decrease of human resilience. Natural hazards influence upon the natural resources of these islands and income sources of the inhabitants and forced them to migrate. Intra-island migrations are far more prominent than towards mainland or towns. Migrants prefer areas with similar environment, near shore or riverbank as their destination mostly. Theses migrants often struggles to sustain their life in their destined places. Seasonal circular migration or movement of the working male persons of the study areas are very much unique characteristics of this off-shore islands. This migration occurs mainly towards nearby coastal towns and cities from mid-December to mid-June. This is a measure of adaptation to climate change mainly - to sustain or improve the present socio-economic status they are in.

\section{References}

Abella M (1994) Turning points in labor migration, Asian and Pacific Migration Journal 3(1): 1-7.

Adger WN, Hughes TP, Folke C, Carpenter SR, Rockstrom J (2005) Social - ecological resilience to coastal disasters. Science 309: 1036-1039.

Ahmad M (2003) Coastal Livelihoods an introductory analysis. Working Paper. PDO- ICZM, Dhaka

Alam MR (2012) Climate change and its impact on health and livelihood within Hatiya Island of Bangladesh. J. Agro for. Environ. 6(2): 13-16.

Bangladesh Bureau of Statistics, 1983, 1991, 2001, 2012. The Statistica Year Book. Dhaka: Bangladesh Bureau of Statistics

Barman SD, Majumder SC, Rahaman MZ, Sarker S, (2012) Foundations of Migration from the Disaster Consequences Coastal Area of Bangladesh. Developing Country Studies 2(4):22-29.

BCA (2004) GIS-Bangladesh Country Almanac (BCA): A User Friendly GIS Tool for Agricultural, Forestry and Natural Resource Management. Project. BARC, Dhaka.

Black R, Kniveton D, Schmidt-Verkerk K (2011) Migration and climate change: towards an integrated assessment of sensitivity. Environment and Planning 43: 431-450.

Black R (2001) Environmental refugees: myth or reality? UNHCR Working Paper 34.

Brown O (2007) Climate change and forced migration: Observations, projections and implications. UNDP. Geneva

Castles S (2002) Environmental change and forced migration: making sense of the debate. UNHCR Working Paper 70.

Climate Change Cell (2009) Characterizing Long-term Changes of Bangladesh Climate in Context of Agriculture and Irrigation. Climate Change Cell, DoE, MoEF, Dhaka

Hussein K, Nelson J (1999) Sustainable Livelihoods and Livelihood Diversification. IDS Working Paper 69. Institute of Development Studies, Brighton.

ICZMP (2003) Delineation of the Coastal Zone. Dhaka: Integrated Coastal Zone Management Project.

IOM (2010) Assessing the Evidence: Environment, Climate Change and Migration in Bangladesh. International Organization for Migration.

IPCC (1990) IPCC AR1 - Working Group II: Impacts Assessment of Climate Change. IPCC.

Islam T, Neelim A (2010) Climate Change in Bangladesh. The University Press Limited, Dhaka. 
Khan IA, Ali Z, Asaduzzaman M, Bhuyan RMH (2010) The Social Dimensions of Adaptation to Climate Change in Bangladesh. The World Bank, New York.

Lein H (2010) Hazards and 'forced' migration in Bangladesh. Norwegian Journal of Geography, 54(3): 122-27.

Mahbub AQM (1997) Mobility behaviour of Working People in Bangladesh. Dhaka: Urban Studies Forum (USP), Department of Geography and Environment, University of Dhaka, Dhaka.

Martin SF (2009) Managing environmentally induced migration', in Migration, Environment and Climate Change: Assessing the Evidence. Eds Laczko F, Aghazarm C (International Organization for Migration, Geneva), pp. 353-384.

McLeman R, Smit B (2006) Migration as an adaptation to climate change. Climate Change, (76): 31-53

Ministry of Environment and Forests (2009) National Adaptation Programme of Action (NAPA), Dhaka.

Mimura N, Nurse L, McLean RF, Agard J, Briguglio L, et al. (2007) Small islands. Climate change 2007: impacts, adaptation and vulnerability. In Contribution of Working Group II to the Fourth Assessment Report of the Intergovernmental Panel on Climate Change, ed. ML Parry, OF Canziani, JP Palutikof, PJ van der Linden, CE Hanson, pp. 687716.

Ministry of Environment and Forests, 2009. Natonal Adaptation Programme of Action (NAPA). Government of Peoples Republic of Bangladesh, Dhaka.

Nabi NAKM (1992) Dynamics of Internal Migration in Bangladesh. Canadian Studies in Population 19: 8198.

Nielsen SLP, Battig MB (2008) Exploring the link between climate change and migration. Climate Change 91: 375-393.

Newland K (2011) Climate Change and Migration Dynamics. Migration policy Institute, Washington, DC.

Oliver SA (2010) Defying Displacement: Grassroots Resistance and the Critique of Development. Univ.Texas Press. Austin.

Quarantelli EL (1985) What is a disaster? The need for clarification in definition and conceptualization in Research. In: Sowder B (ed.) Disaster and mental health - Selected contemporary perspectives. US Goverbment Printing Office, Washington DC, pp. 41-73

Raleigh C, Jordan L (2010) Climate change and migration: emerging patterns in the developing world. In: Mearns R, Norton A (eds.) Social
Dimensions of Climate Change. World Bank. Washington, DC.

Rayhan I, Grote U (2007) Coping with floods: Does rural-urban migration play any role for survival in rural Bangladesh? J. Ident. Migrat. Stud. 1: 82-98.

Sarker M, Choudhury E (2003) Knowledge Portal on Estuary Development (KPED). Working Paper. Dhaka: Water Resources Planning Organization (WARPO) CEGIS.

Scheffran J, Battaglini A (2011) Climate and conflicts: the security risks of global warming. Environmental Change 11(Suppl 1): 27-39

Stern N (2010) The Economics of Climate Change: The Stern Review, HM Treasury. London

Zelinsky W (1971) The Hypothesis of the Mobility Transition. Geographical Review 2: 225. 